\title{
Coordination of the U.S. DOE-Argentine National Atomic Energy Commission (CNEA) Science and Technology Implementing Arrangement
}

Final Report
January 1998

By:

M. A. Ebadian
RECEIVED

OCT 131998

O. STI

Work Performed Under Contract No.: DE-FG21-95EW55094

For

U.S. Department of Energy

Office of Fossil Energy

Federal Energy Technology Center

P.O. Box 880

Morgantown, West Virginia 26507-0880

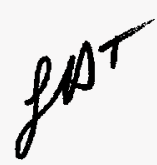

By

Florida International University

Hemispheric Center for Environmental Technology (HCET)

Center for Engineering \& Applied Sciences

10555 West Flagler Street

EAS-2100

Miami, Florida 33174

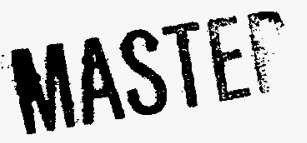




\section{Disclaimer}

This report was prepared as an account of work sponsored by an agency of the United States Government. Neither the United States Government nor any agency thereof, nor any of their employees, makes any warranty, express or implied, or assumes any legal liability or responsibility for the accuracy, completeness, or usefulness of any information, apparatus, product, or process disclosed, or represents that its use would not infringe privately owned rights. Reference herein to any specific commercial product, process, or service by trade name, trademark, manufacturer, or otherwise does not necessarily constitute or imply its endorsement, recommendation, or favoring by the United States Government or any agency thereof. The views and opinions of authors expressed herein do not necessarily state or reflect those of the United States Government or any agency thereof. 


\section{DISCLAIMER}

Portions of this document may be illegible in electronic image products. Images are produced from the best available original document. 


\section{TABLE OF CONTENTS}

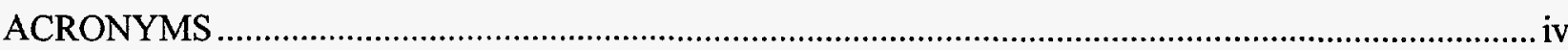

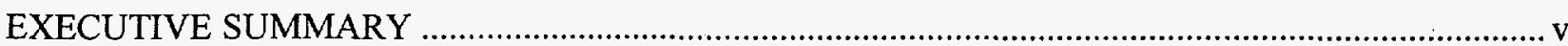

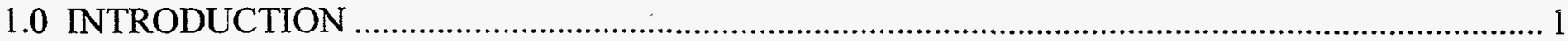

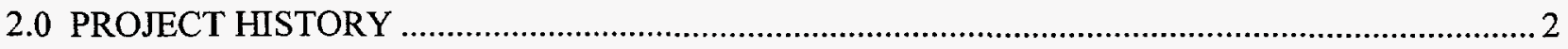

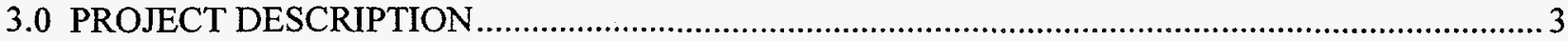

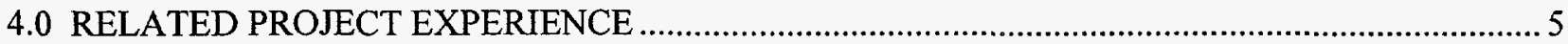

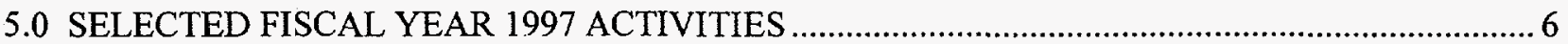

5.1 PREPARATION OF OPERATING PROCEDURES GOVERNING THE TECHNICAL AND ADMINISTRATIVE ACTIVITIES OF THE JCCRM .......................... 6

5.2 COORDINATION AND TRACKING OF ALL TECHNICAL AND ADMINISTRATIVE WORK PERFORMED UNDER THE AUSPICE OF THE JCCRM

5.3 HOSTING OF U.S. DEPARTMENT OF ENERGY/NATIONAL ATOMIC ENERGY COMMISSION OF ARGENTINA FOURTH U.S./ ARGENTINA COMMITTEE MEETING FOR RADIOACTIVE AND MIXED WASTE MANAGEMENT.

5.4 ADVANCEMENT OF DOE/CNEA JCCRM ACTIVITIES THROUGH

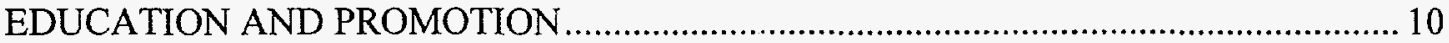

5.5 CONTINUATION OF DEVELOPMENT OF CONTACTS ........................................... 12

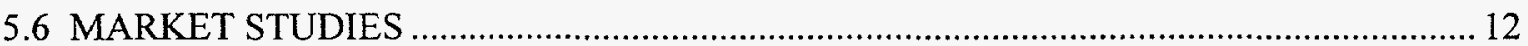

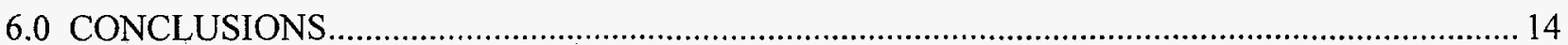

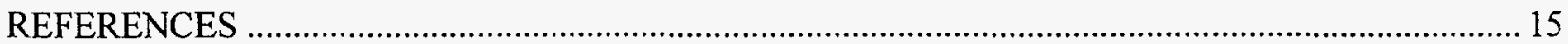

APPENDIX A: U.S. DOE - ARGENTINA CNEA ANNUAL REPORT ON JCCRM ACTION ITEMS '98

APPENDIX B: U.S. DOE - ARGENTINA CNEA ANNUAL REPORT ON JCCRM ACTION ITEMS '97

APPENDIX C: STATUS OF SPANISH NUCLEAR ENERGY MARKET 


\section{ACRONYMS}

$\begin{array}{ll}\text { DOE } & \text { U.S. Department of Energy } \\ \text {-EM } & \text { Environmental Management (DOE) } \\ \text {-OST } & \text { Office of Science and Technology (DOE) } \\ \text {-HQ-IPO } & \text { Headquarters International Program Officer (DOE) } \\ \text { CNEA } & \begin{array}{l}\text { Comisión Nacional de Energía Atómica (National Atomic Energy } \\ \text { Commission, Argentina) }\end{array} \\ \text { JCCRM } & \text { Joint Coordinating Committee for Radioactive and Mixed Waste } \\ & \text { Management } \\ \text { ROM } & \text { Record of Meeting } \\ \text { FIU } & \text { Florida International University } \\ \text { HCET } & \text { Hemispheric Cente: for Environmental Technology }\end{array}$




\section{EXECUTIVE SUMMARY}

In 1989, The U.S. Department of Energy (DOE) established the Office of Environmental Management (EM) and delegated to the office the responsibility of cleaning up the U.S. nuclear weapons complex. EM's mission has three primary activities: 1) to assess, remediate, and monitor contaminated sites and facilities; 2) to store, treat, and dispose of wastes from past and current operations; and 3) to develop and implement innovative technologies for environmental remediation.

To this end, EM has established domestic and international cooperative technology development programs, including one with the Republic of Argentina. Cooperating with Argentine scientific institutes and industry meets U.S. cleanup objectives by: 1) identifying and accessing Argentine EM-related technologies, thereby leveraging investments and providing cost-savings; 2) improving access to technical information, scientific expertise, and technologies applicable to EM needs; and 3) fostering the development of innovative environmental technologies by increasing U.S. private sector opportunities in Argentina in EM-related areas.

Florida International University's Hemispheric Center for Environmental Technology (FIUHCET) serves as DOE-OST's primary technology transfer agent. FIU-HCET acts as the coordinating and managing body for the Department of Energy (DOE)-Argentina National Atomic Energy Commission (CNEA) Arrangement. Activities include implementing standard operating procedures, tracking various technical projects, hosting visiting scientists, advising DOE of potential joint projects based on previous studies, and demonstrating/transferring desired technology. HCET hosts and directs the annual Joint Coordinating Committee for Radioactive and Mixed Waste Management meeting between the DOE and CNEA representatives. Additionally, HCET is evaluating the possibility of establishing similar arrangements with other Latin American countries. 


\subsection{INTRODUCTION}

In May 1996, the United States Department of Energy and the Republic of Argentina's National Atomic Energy Commission (Comisión Nacional de Energía Atómica) signed the Implementing Arrangement between the Department of Energy of the United States of America and the National Atomic Energy Commission of the Argentine Republic for Technical Exchange and Cooperation in the Area of Radioactive and Mixed Waste Management. It is a science and technology arrangement to exchange information and technologies used to manage radioactive and mixed waste. The Implementing Arrangement establishes a U.S./Argentine Joint Coordinating Committee for Radioactive and Mixed Waste Management (JCCRM) to oversee all of its aspects.

The objectives of the cooperation under this Arrangement are to study radioactive and mixed waste management activities on the basis of mutual benefit, equality, and reciprocity and to develop the technologies and techniques necessary to achieve this objective. The technical application areas covered under the Arrangement include, but are not limited to, decontamination and decommissioning; waste preparation and packaging; site characterization, monitoring, and modeling; site remediation, including remote operations; and waste management, including waste treatment, interim storage, and final disposal.

The cooperative activities that are expected to be undertaken and which are governed by the Arrangement include the exchange of information and data on scientific and technical activities; the exchange of scientists, engineers, and other specialists for work at research centers; shortterm visits and assignment of staff; organization of workshops and seminars; exchange and provision of equipment and samples; and the execution of joint studies and projects.

HCET is playing a key role in the implementation of the Arrangement. It has served as the single, independent point of contact for the coordination and facilitation of all activities occurring under the Arrangement. DOE has selected HCET for this role because of the expertise of staff and because its capabilities include those required to perform the work of coordinator and technical contributor. 


\subsection{PROJECT HISTORY}

During the course of initial technical exchanges between DOE and Argentina's CNEA, both parties determined that their remediation objectives will benefit from a mutual exchange of technologies and expertise. The implernenting arrangement between DOE and CNEA was signed to provide an international vehicle for such an exchange. The CNEA is interested in applying U.S. DOE-developed environmental technologies in Argentina. In addition to having an interest in the CNEA's solutions to radioactive waste problems, DOE is interested in the performance data generated from the application of U.S. technologies in Argentina.

For the Implementing Arrangement to accomplish the objectives envisioned by DOE and CNEA, an independent organization was chosen to coordinate the work performed under the Arrangement. This organization must have a unique combination of skills that include technical expertise, an understanding of cultural issues involved in working with a foreign government (including appropriate foreign language skills), first-hand knowledge of DOE and its requirements and experience in technology transfer, and a proven ability to perform the coordination cost effectively in order to keep the administrative costs low. DOE selected FIUHCET as the coordinating body for the: Arrangement. 


\subsection{PROJECT DESCRIPTION}

HCET's work on this project provides DOE with a single independent point of contact for the coordination and facilitation of all activities occurring under the cooperative arrangement.

HCET's combination of skills includes technical expertise in certain areas covered by the agreement:

- Experience in work with individuals and organizations from Latin America

- Expert Spanish language skills

- First-hand knowledge of DOE and its rules, regulations, and reporting requirements

- Experience in technology transfer; and a cost-effective organizational structure.

These skills enabled HCET to interact with all parties involved in this cooperative work, and to be part of all DOE-prescribed activities to be undertaken by these parties.

The expected focus of the work consisted of 1) preparing procedures and policies governing all technical and administrative work that will take place under the Implementing Arrangement, 2) gathering technical information about the waste management needs of the CNEA, 3) coordinating all technical and administrative work that will be conducted under the Implementing Arrangement (which will encompass technical projects and specific actions assigned to various parties by DOE and CNEA), and 4) developing a monthly report describing all the activities that took place each month as part of the Implementing Arrangement.

Under the JCCRM, a variety of activities were authorized, including holding technical workshops, technology development, technology deployment, and scientist exchange. Details of these activities appear in Appendix A and B of this report. These directly support EM's Focus Areas and Crosscutting Programs, which include the technical areas:

- Decommissioning and decontamination

- Contaminant transport and site characterization

- High-level waste tank remediation

- Separations

- Mixed waste

- Plutonium stabilization

- Subsurface contamination.

At the first JCCRM meeting, participants defined three areas of cooperation including remediation of uranium mill tailings, decommissioning and decontamination, and research and development of low and high-level waste. This list was later expanded to include characterization and retrieval (of spent resins), separations methods (e.g., crystalline silicotitinate), and vitrification processes. 
The project's purpose grew to include a fifth function: identifying projects within Latin American and Caribbean countries that would support the DOE's mission of facilitating the demonstration and transfer of U.S. environmental technologies throughout the region. This has included identifying the most mature and lucrative markets for environmental goods and services; the markets that have the greatest growth potential; and the countries that exhibit the greatest openness to trade in this sector. This function will also determine, by scope and severity, the most important environmental needs in each of these markets; the types of solutions used or being considered to satisfy these needs; and the most important players, both private and public, in each country. In addition, HCET intends to identify other emerging markets that exhibit potential for future growth and development once their formative stage is complete. 


\subsection{RELATED PROJECT EXPERIENCE}

This project developed from the success of the FY96 project, Latin America's Decontamination and Decommissioning Needs. The purpose of that earlier project was to identify the Latin American and Caribbean countries that had the most mature and lucrative markets for environmental goods and service, the markets that had the greatest growth potential, and the countries that exhibit the greatest openness to trade in this sector. The program also intended to determine, by scope and severity, the most important environmental needs in each of these markets; the types of solutions used or being considered to satisfy these needs; and the most important players, both private and public, in each country. In addition, the Latin American and Caribbean program intended to identify other emerging markets that exhibit the potential for future growth and development once their formative stage is complete.

The project emphasized developing contacts with academics, businesspersons, government officials, and others currently working on or researching issues related to sustainable development and environmental technology in Latin America. These individuals assisted in identifying the most salient environmental issues that require applied environmental technology in Latin America and the Caribbean.

A full report of this completed project was prepared for the U.S. DOE-EM Office of Science and Technology entitled, "Final Report: Latin America's Decontamination and Decommissioning Needs," published by HCET, 1997. 


\subsection{SELECTED FISCAL YEA,R 1997 ACTIVITIES}

During the past year, HCET has successfully performed its coordinating duties, which included assessing the 'needs' of each organization, reviewing and recommending joint projects, coordinating work performed towards agreed upon Action Items, reporting on status of said Action Items, facilitating communication between parties (including translation services), hosting scientists traveling on fact finding and work missions, hosting and facilitating annual JCCRM meetings, developing procedures used in the management of the processes of the Arrangement, and performing other duties as requested by the DOE-HQ-IPO.

Additionally, HCET assisted DOE on its third objective of improving foreign market access to U.S. environmental technologies. This was completed by developing contacts with key agencies and industries throughout the Western Hemisphere, and by developing an understanding of the needs and markets of these countries. Market studies were also conducted to provide more specific knowledge in key environmental sectors. These activities served a dual purpose in that they also facilitated the transfer of technical information, scientific expertise, and innovative technologies which assists the DOE in their remediation efforts.

\subsection{PREPARING OPERATING PIROCEDURES THAT GOVERN THE TECHNICAL AND ADMINISTRATIVE ACTIVITIES OF THE JCCRM}

A U.S. Department of Energy (DOE)/Argentine National Atomic Energy Commission (Comisión Nacional de Energía Atómica, CNEA) Joint Coordinating Committee for Radioactive and Mixed Waste Management (JCCRM) was established under the Implementing Arrangement between the Department of Energy of the United States of America and the National Atomic Energy Commission of the Argentine Republic for Technical Exchange and Cooperation in the Area of Radioactive and Mixed Waite Management (hereinafter referred to as Implementing Arrangement) signed in May 1996, by the United States and the Republic of Argentina. Under the JCCRM, a variety of activities are authorized, including technical workshops, technology development, technology deployment, and scientist exchanges.

At the request of the DOE-OST, HCET developed procedures, "Operating Procedures for the Activities of the JCCRM-Under the Auspices of the Implementing Arrangement between the U.S. Department of Energy and Argentina's National Atomic Energy Commission," which outlined the operating process for technical and administrative activities performed by any and all parties in the United States. The:se procedures cover all aspects of project implementation including: proposal development, the management of DOE/CNEA projects, and resolving action items from a Joint Coordinating Committee for Radioactive and Mixed Waste Management (JCCRM) Record of Meeting (ROM) . A brief description of each procedure follows.

\section{Procedures for Proposal Development}

The procedures outline the process for placing a call for proposals for the DOE/CNEA projects, directing proposal development, and responding to a call for proposals. This is done through the following activities: 
- needs assessment

- needs assessment exchange

- project definition

- selection of project participants

- identification of technical capabilities

- call for proposals

- proposal scope

- proposal evaluation

- joint international proposals

- project confirmation.

\section{Procedures for the Management of DOE/CNEA Projects}

These procedures define DOE's process of conducting the DOE/CNEA projects within the DOE complex through the following activities:

- establishment of the project

- project variance

- reporting

- communication

- material disposition.

Procedures for Resolving Action Items from a Joint Coordinating Committee for Radioactive and Mixed Waste Management (JCCRM) Record of Meeting (ROM)

These procedures define DOE's process of assigning responsibility for, tracking the progress of, and documenting the completion of the DOE action items contained in the ROMs.

- record of meeting preparation

- responsibility for the assignments of action items

- concurrence requirements for action items

- communication between U.S. and Argentine participants

- reporting requirements

- tracking of action items

- completion of the action items

- closure of a record of meeting. 
The intent of these procedures is to assist those working on JCCRM projects, informing them of the standards under which activities are to be carried out. The procedures have been delivered to those individuals whom are currently working on a project, and will continue to be distributed as needed.

\subsection{COORDINATING AND TRAC|KING OF ALL TECHNICAL AND ADMIINISTRATIVE WORK PERFORMED UNDER THE AUSPICE OF THE JCCRM}

Because HCET was the key contact for these projects, it was HCET's responsibility to distribute all relevant records to appropriate project personnel. HCET also acted as the conduit for the information flow between the U.S. and Argentina, facilitating telephone conference calls, and making necessary arrangements for the translation of technical information.

The work included the gathering of 'needs' information from each organization so as to recommend potential future projects. This was conducted through repeated conversations with personnel from the DOE Focus Areas and the CNEA. The assembly of this information facilitated the preparation of Requests for Proposals (RFPs) and the eventual evaluation and distribution of these projects. For those projects which were already determined (See Appendix B -FY97 Action Items), close monitoring of them was conducted to keep the different parties involved within each project informed.

Under the auspices of the U.S./Argentina Joint Coordinating Committee for Radioactive and Mixed Waste, projects were carried out in both countries by a variety of institutions and individuals. HCET was tasked to corrdinate, track, and report on the status of these projects, ensuring a smooth and productive outcome. For this purpose, HCET added to its personnel a bilingual (Spanish/English) International Coordinator, who served as the principal coordinator for all of HCET's work performed as part of this project.

For the Department of Energy-Head Quarters-International Program Officer (DOE-HQ-IPO), HCET reported on a monthly basis the status of each JCCRM-established action item. For this, HCET receives a monthly update from each of the principle investigators. This information can be formulated into a comprehensive report for all projects and distributed to parties identified by the DOE-HQ-IPO. 


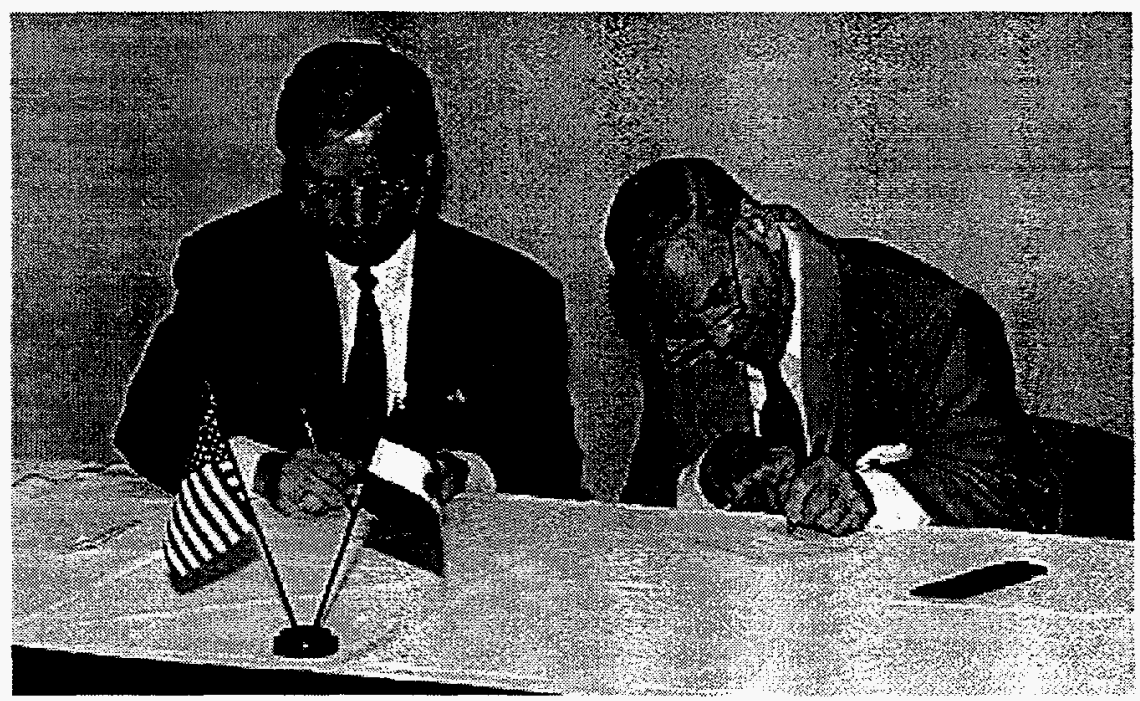

Figure 1. Gerald Boyd, acting deputy assistant secretary, Office of Science and Technology, U.S. DOE (left) and Jaime Pahissa-Campa, Member Board of Directors, Argentina National Atomic Energy Commission sign into effect the Record of Meeting of the Fourth JCCRM meeting.

\subsection{HOSTING OF U.S. DEPARTMENT OF ENERGYINATIONAL ATOMIC ENERGY COMMISSION OF ARGENTINA FOURTH U.S.IARGENTINA COMMITTEE MEETING FOR RADIOACTIVE AND MIXED WASTE MANAGEMENT}

One aspect of the arrangement between the U.S. DOE and Argentina's CNEA is the annual meeting of the Joint Coordinating Committee for Radioactive and Mixed Waste Management. This meeting, which HCET coordinated and hosted, is used by both parties to review past projects, exchange information on current projects, and plan future activities.

The Fourth JCCRM meeting was held in Miami, Florida December 3 and 4, 1997. The Argentina delegation was led by Dr. Jaime Pahissa-Campa, Advisor of the CNEA and President and Director of the Waste Management Program. The U.S. delegation was led by Gerald Boyd, acting deputy assistant secretary for the Office of Science and Technology, DOE Office of Environmental Management (EM).

The meeting was divided into two sections: a review of FY97 activities, and planning for FY98. HCET provided information regarding the status of FY97 action items, since it had been tracking the work performed by both the US and Argentine officials. Likewise, HCET assisted in planning future activities.

A copy of the FY97 and FY98 action items are in Appendix A and B respectively. 


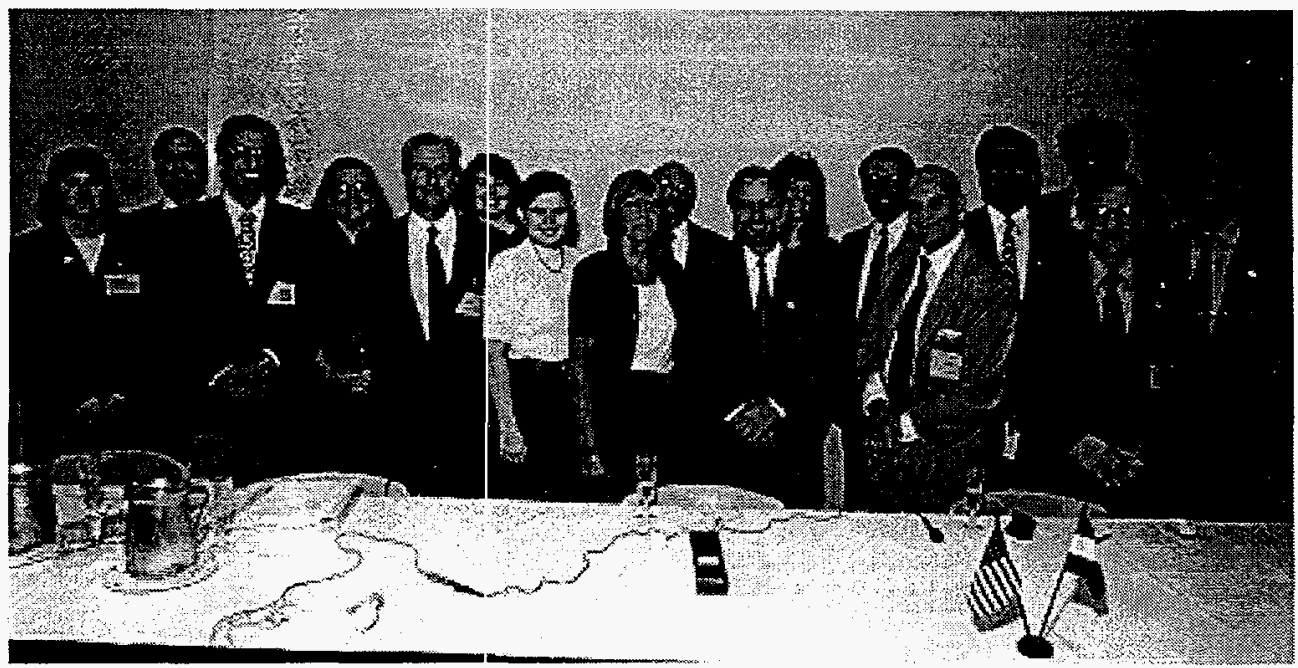

Figure 2. U.S. and Argentina representatives to the $4^{\text {th }}$ JCCRM meeting held at X-change '97, D\&D Global Marketplace Conference held in Miami, Florida in December 1997.

\subsection{ADVANCING DOE/CNEA JCCRM ACTIVITIES THROUGH EDUCATION AND PROMOTION}

HCET continuously strives to inform both the private and public sectors about the Implementation Arrangement. HCET has concentrated on identifying other organizations which might assist in the Arrangement because of their expertise in a specific area. This included private industry which might provide a new technology for an identified remediation project and public organizations which could facilitate the flow of information between sectors.

HCET also explored the possibility of establishing a similar arrangement with other countries. This involved identifying countries that had similar needs, technology programs that could supply new information/practices that would assist DOE in its mission, and an infrastructure (i.e.: organization, personnel, and budget) which would support such a program.

To accomplish these objectives, HCET arranged a number of meetings with foreign dignitaries, and attended a variety of workshops/conferences. A selected list follows:

Hemispheric Energy Steering Committee, Miami, Florida

HCET participated in this forum which directs the Hemispheric Energy Initiatives derived from the Summit of Americas. HCET interacted with Latin American and Caribbean government officials to explore future collaboraticns.

\section{Natural Gas \& Electric Power Integration in the Southern Cone, Montevideo, Uruguay}

HCET served as a moderator on a panel with government representatives from the energy sector, examining ways the countries of the Southern Cone could collectively increase and facilitate market assess. HCET presented a program about the Implementing Arrangement between DOE 
and Argentina and its international programs/capabilities. This provided an excellent opportunity for HCET to further increase the visibility of this arrangement and continue to strengthen its relations with other countries.

\section{Higher Education/Federal Government Linkages, Miami, Florida}

The DOE asked HCET to present its collaboration with the DOE's international programs for the purpose of informing other entities of its mutually beneficial results. This allowed HCET to explore the capabilities of other agencies, examining how specific partnership could increase the success of DOE's mission.

\section{ENVIRO-PRO' '97, Mexico City, Mexico}

This fact-finding/trade mission allowed HCET to meet with numerous nuclear and environmental remediation entities throughout North America and Mexico. The development of these contacts facilitated HCET's ability to perform for the DOE and increase the opportunities for U.S technologies.

\section{National Association of Development Agencies, Miami, Florida}

HCET was asked to deliver two presentations at this conference, one on the Latin America and Caribbean environmental technology marketplace and the second on HCET's international operations with the DOE. This allowed for the exploration of potential partnerships with other development agencies.

\section{X-change 97: The Global D\&D Marketplace, Miami, Florida}

Sponsored by DOE and hosted by HCET, this unique conference brought together D\&D representatives from the private, governmental, and public sectors. Over 18 countries were represented by approximately 1,000 people who discussed ways to decrease the cost and risk of decontamination and decommissioning activities. A unique feature of this conference was 'live' technology demonstrations that allowed end users to witness innovative technologies at work and to discuss their specifications directly with the manufacturers.

$X$-change ' 97 also allowed for numerous partnerships to be developed for cooperative pursuit of new technologies and D\&D practices. The trade show portion of the conference featured over sixty exhibitors, and twenty-five operational practice and live technology demonstrations including technology providers, national laboratories, university centers, and DOE sites. This promoted new business generation and the pursuit of global partners among the $1000 X$-change participants.

Conveniently, the Fourth Annual JCCRM meeting was held at $X$-change '97, allowing for both the private sector and other foreign delegates to discuss the benefits produced from the Implementation Arrangement, such as reducing the high cost of research through the establishment of joint projects and allowing foreign technologies to prove their capabilities and perform technology demonstrations. Dr. Jaime Pahissa-Campa, who led the Argentina delegation, gave an opening keynote address stressing the importance of mutually beneficial relations among the countries that have $D \& D$ processes. 


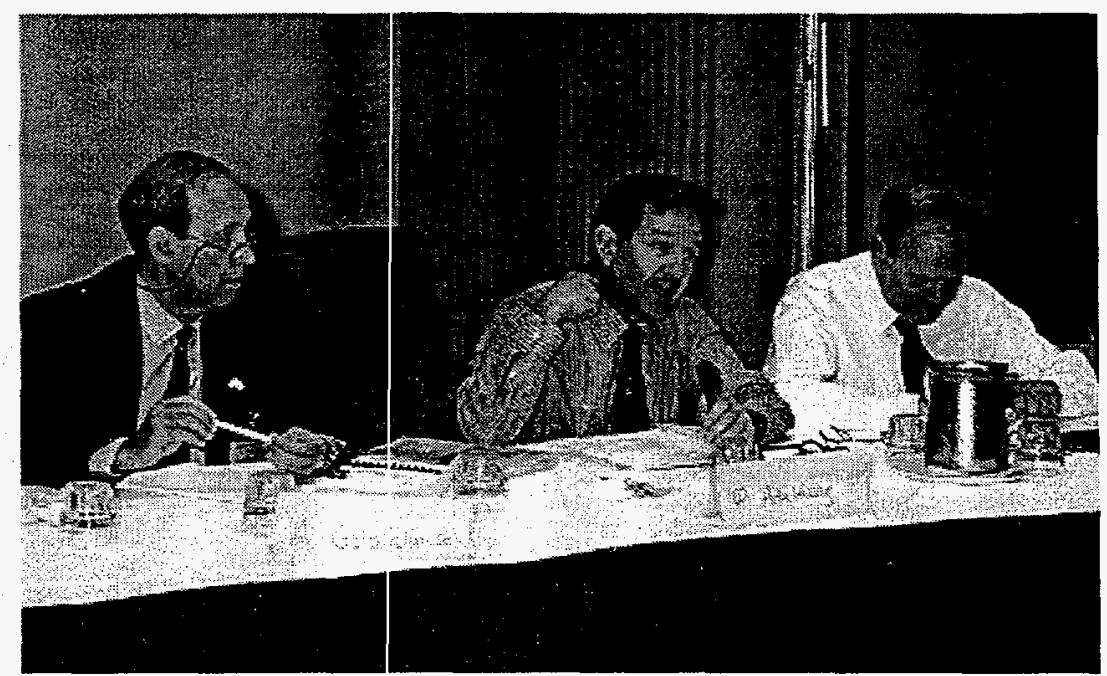

Figure 3. Adrian Gioldschmidt, Pablo Adelfang, and Jaime Pahissa-Campa, delegates from Argentina, presented an overview of CNEA activities.

\subsection{CONTINUATION OF DEVELOPMENT OF CONTACTS}

Throughout FY97, the HCET program coordinator has continued to develop and strengthen relations with various key players in Argentina and other Latin American institutions. The HCET coordinator for the Implementing and the Arrangement has arranged various visitors from government, academia, and private sectors. The visitors have included personnel from both Latin America and the Caribbean as well as the United States.

In addition to developing valuable contacts, HCET's coordinator continued the process of increasing a database on environmental-related institutions and organizations in Latin America and the Caribbean. These entities have been categorized according to their type of activity (e.g., financing, regulation, consulting, engineering, etc.) and scope (e.g., regional, national, governmental, non-governmental, profit, non-profit, etc.) and have been added to HCET's growing database.

The majority of directors of these institutions were contacted and were given an HCET capabilities packet. The purpose of this information campaign is not only to increase the visibility of HCET's operations, but also to seek partnerships that will forward the objectives of DOE and HCET's clients and partners.

\subsection{MARKET STUDIES}

To foster the development of innovative environmental technologies by increasing U.S. private sector opportunities in Argentina in areas related to Environmental Management, HCET procured various market studies tha. will be published and made available. Previously, HCET had identified nuclear and hazardous waste management, municipal and solid waste 
management, air pollution and prevention, and water treatment as the most important environmental concerns in Latin America. The significance of each of these needs varies from one country to another. However, these waste management areas pose the most important challenges and the best investment opportunities.

Through further investigation, in 1996, HCET's research identified Brazil, Chile and Mexico as having the most significant and lucrative environmental technology markets in the region. As a result, comprehensive market studies were commissioned and published for each of these three countries.

To continue the promotion of U.S. technologies, HCET further investigated potential markets among the Spanish speaking countries. It was found that Spain, while not a Latin American country, had the most promising market. After an initial market review conducted by HCET, an international marketing firm was contracted to write a comprehensive environmental technology market assessment. This document is in publication, and will be available with the current reports. A brief summary of this report appears in Appendix C. 


\section{CONCLUSIONS}

The purpose of this project was to assist the DOE in the coordination of an established international cooperative technology development program with the Republic of Argentina. This Arrangement with Argentine is to assist the DOE in meeting its previously identified objectives by: 1) identifying and accessing Argentine environmental management-related technologies, thereby leveraging investments and providing cost-savings; 2) improving access to technical information, scientific expertise, and technologies applicable to EM needs; and 3) fostering the development of innovative environmental technologies by increasing U.S. private sector opportunities in Argentina in EM-related areas. It was also expected that HCET would assist the DOE in the examining other potential partnerships, and would promote U.S. technologies throughout the international community.

All these activities will be continued by HCET in FY98 under the project title, Opportunities to Market U.S. Technologies Throughout the Western Hemisphere. HCET will proceed with its responsibilities as the DOE-OST's primary technology transfer agent for environmental technology and continue to assist DOE-OST with the development and coordination of activities being conducted under the technical arrangement. 


\section{REFERENCES}

Bermudez J., Lagos L., and Mayerle M., 1997. Latin America's Decontamination and Decommissioning Needs, Florida International University Hemispheric Center for Environmental Technology.

Ebadian, M.A., 1996. Hemispheric Center for Environmental Technology FY1997 Project Technical Plan, Florida International University.

U.S. DOE-OST and FIU-HCET, Market for U.S Environmental Technologies and Services in Spain, Prepared for Hemispheric Center for Environmental Technology, Florida International University, Miami, (forthcoming).

U.S. DOE-OST and FIU-HCET, 1997. Operating Procedures for the Activities of the JCCRM, U.S. Department of Energy. 
U.S. DOE - ARGENTINA CNEA ANNUAL REPORT ON JCCRM ACTION ITEMS '98 


\section{U.S. DOE - ARGENTINA CNEA ANNUAL REPORT ON JCCRM ACTION ITEMS ‘98}

Reporting on the Resolution of Action Items between U.S. Department of Energy and Argentina National Commission of Atomic Energy, under the Science and Technology Implementing Arrangement for Cooperation on Radioactive and Mixed Waste Management (JCCRM)

Action Items taken from Record of Meeting of the Fourth Joint Coordinating Committee for Radioactive and Mixed Waste Management held December 3 - 4, 1997.

1) a) DOE will provide CNEA information and contacts at Union Oil Products so they may pursue receiving samples of Crystalline Silicotinate (CST) sufficient for CNEA evaluation.

b) CNEA will contact and negotiate a non-disclosure agreement with UOP.

2) DOE and CNEA will collaborate on conducting cold and host tests of CST material, upon completion of Action Item \#1. This will include further analysis, design activities, and disposal options which will be determined cooperatively. A proposal for CST work will be completed February 1, 1998.

3) DOE to provide CNEA with reports on irradiation tests regarding Radiolysis Studies on Argentina Ion Exchange Material. These were prepared from characterization information provided by CNEA on ion exchange resins from the Embalse and Atucha power plants.

4) DOE to provide samples of glass (vitrification tests) to CNEA along with the American Society of Testing Materials (ASTM) durability procedures.

5) DOE will contact Civilian Radioactive Waste Management (RW) and request that they respond to CNEA's interest in collaborating on technical projects for which RW has responsibility.

6) DOE and CNEA will collaborate together on the Integrating Contractor Team of the large scale demonstrations for the D\&D of Plutonium gloveboxes. These will be conducted at Los Alamos National Laboratory. A detailed plan of how participation will proceed will be completed by April 1998.

7) DOE and CNEA will collaborate on resin testing in the melter at Clemson University. DOE will arrange a scientist exchange for CNEA at Clemson University for this testing. Testing will be conducted on samples of CNEA's nuclear power plant non-radioactive resins which they will prepare. CNEA will provide technical results of all resin characterization work. A proposal for the resin testing work, along with the schedule of proposed activities, will be completed by February 1 , 1998.

8) DOE will provide the Hanford LLW product acceptance criteria to CNEA.

9) Upon its release, DOE will provide the Savannah River Site report on resin vitrification to CNEA.

10) DOE to provide CNEA with information regarding recommendations for a melter for CNEA, including manufacturers, suppliers, and costs.

11) CNEA will provide DOE with a final report of Argentina fusion and sintering resins results.

12) CNEA will provide their uranium mill tailings plan to DOE for review and consideration for possible future cooperation 
U.S. DOE - ARGENTINA CNEA ANNUAL REPORT ON JCCRM ACTION ITEMS ‘97 


\section{U.S. DOE - ARGENTINA CNEA ANNUAL REPORT ON JCCRM ACTION ITEMS ‘97}

Reporting on the Resolution of Action Items between U.S. Department of Energy and Argentina National Commission of Atomic Energy Under the Science and Technology Implementing Arrangement for Cooperation on Radioactive and Mixed Waste Management (JCCRM).

\section{Action Items}

1) DOE to provide CNEA two studies: System Integrated Thermal Systems, Non-thermal Treatment Systems within the next 30 days.

2) A scientist exchange between DOE and CNEA in the areas of pretreatment, treatment, transportation, storage and disposal for a period of approximately three to six months. DOE will send a letter of invitation to CNEA within the next 30 days. Florida International University (HCET) will be the home base for this exchange and will provide the coordination through the DOE EM-50 International Office.

3) DOE to provide report on super-critical carbon dioxide treatment of cement (Louisiana State University) within the next 30 days.

4) DOE to provide reports on the current state of Crystalline Silicotitinate (CST) research and manufacturing data within the next 30 days.

5) CNEA to provide engineering assessment of the spent resin pools in Embalse and Atucha along with chemical composition and tank dimensions by March 30, 1997.

6) Samples of IX resins will be loaded with non-radioactive cesium, irradiated to doses expected for 10 years storage, followed by analysis of the resulting slurries and the vapor space above them. The intent is to provide data necessary for sampling, agitation systems as well as potential safety systems.

7) The Argentina data on Mo-99 waste stream will be inserted into the model of CST performance to determine decontamination factors to include precipitation followed by treatment by CST.

8) Tests will be performed to establish the applicability of vitrification of Argentine IX materials.

- The group at Bariloche will perform initial characterization of resins to be tested. Target completion: April 1997

- Argentine and U.S. personnel will vitrify these resins at Clemson University and characterize the product. Target completion July 1997

- U.S. and Argentine personnel will characterize the products using Argentine methodology, and issue a joint report. Target completion September 1997

9) Visit(s) by an Argentine scientist to observe the demonstration of relevant D\&D technologies in the United States. If accepted, CNEA will designate the appropriate scientist, and the visit arrangements will be made through Florida International University. The time frame would be in the FebruaryMay, 1997 period. DOE will provide a letter of invitation detailing the arrangements for the visit. 
10) DOE and CNEA will jointly establish performance specifications for the characterization and decontamination of the plutonium-sontaminated glove boxes in the Alpha Laboratory in the February-May, 1997 period.

11) Demonstration of one or more technologies to characterize one glove box in the Alpha Laboratory by May 1997.

12) Demonstration of one or more technologies to decontaminate the characterized glove box by October, 1997.

13) Demonstration of one or more technologies (different from those in \#11 above) to characterize a second glove box in the Alpha Laboratory by October 1997. 
STATUS OF SPANISH NUCLEAR ENERGY MARKET 


\section{STATUS OF SPANISH NUCLEAR ENERGY MARKET \\ Extract from Market for U.S. Environmental Technologies and Services in Spain, Produced by U.S. DOE-OST and FIU-HCET}

In 1984, Real Decree 1522/1984, created the National Company of Radioactive Waste (ENRESA) to manage all the radioactive waste generated in Spain.

There is also a fuel elements factory, Juzbado, in the province of Cordoba, in the region of Andalusia. Currently, over 35 percent of the electricity used in Spain is generated by nuclear energy. However, despite Spain's heavy dependence on nuclear power, there are no plans to build additional nuclear power plants. Much of the reason for this is the growing public sentiment against the nuclear industry. Spaniards, unlike their French neighbors, do not feel comfortable with either the power stations or the issue of nuclear waste.

Low-and-medium-level nuclear wastes are generated by the power stations and the fuel element plant, Juzbado. The Center for Energy, Environment and Technology Investigations (CIEMAT), and small producers such as hospitals and clinics are also generators of low-and-medium-level nuclear wastes. The high-level nuclear wastes are made up of the spent fuel elements from the nuclear power stations.

The wastes require limited services. The low-and-medium-level waste must be characterized. must undergo some treatment, must be transported and then stored. These services are supplied and carried out by ENRESA itself. All low-and-medium-level radioactive wastes are stored in one facility in Spain, El Cabril.

The spent fuel elements are another matter. Spain, like the United States, currently has no longterm storage facility for high-level nuclear waste. And like in the U.S., the nuclear power stations are presently holding these spent elements in storage pools on site. These various facilities are running out of space. ENRESA is now working on increasing the capacity of the pools at each nuclear plant and is also trying to increase storage capacity with the use of metallic containers.

Meanwhile, ENRESA is trying to choose a permanent location for long-term storage of Spain's high-level radioactive waste. They have chosen several preliminary sites, but are receiving heavy public opposition to both the need for nuclear power and for safe, long-term disposal sites.

The other problem ENRESA faces with its nuclear power stations is the aging of the facilities themselves. One plant, Vandellos 1, in Asturia has been taken off-line. Plans for decommissioning the facility are in progress but are proceeding slowly. The facility is jointly owned by the Spanish and French governments. It has, therefore, been decided that the French, through the public utility Electricite de France, will take responsibility for the spent fuel elements. These will be transported back to France for reprocessing.

ENRESA then plans to demolish all of the buildings without radioactive problems. The nuclear reactor and the building housing will be left until better plans for its dismantling can be created. ENRESA actually envisions leaving this for up to 30 years.

Spain does not have any radioactive contaminated sites. 


\section{Possible Market Opportunities for U.S. Firms}

While the Spanish nuclear industry market is limited, there are some nuggets of opportunity. Though it is highly unlikely that Spain will build any more nuclear power stations, there are plans to upgrade and lengthen the life of the present stations. ${ }^{1}$ This upgrading will include steam generators and turbine replacement and upgrades. This opens opportunities for not only selling the new equipment but for decommissioning of the old parts.

Additionally, while ENRESA has not voiced any decision on how or when it will decommission the Vandellos1 plant in Asturia, it would be recommended that any firm with the knowledge and experience in doing such work approach ENRESA. ENRESA is known to have substantial funding, and a progressive stance with them could lead to decommissioning studies and actual work for the plant's decommissioning. It should be noted, however, that it is likely that the French are already exploring such options.

1 Ashton, Jack. "Spanish N-Plant Production Hitsi New Record", NucNet February 20, 1997. 